\title{
SEMI-EMPIRICAL SOFTWARE FOR THE ALUMINOTHERMIC AND CARBOTHERMIC REACTIONS
}

\author{
Milorad Gavrilovski ${ }^{1}$, Vaso Manojlovic ${ }^{2 *}$, Željko Kamberović ${ }^{1}$, Marija Korać ${ }^{1}$, \\ Miroslav Sokić ${ }^{2}$ \\ ${ }^{1}$ Faculty of technology and metallurgy, Karnegijeva 4, University of Belgrade, \\ Serbia \\ ${ }^{2}$ Institute for technology of nuclear and other mineral raw materials, \\ Franše d' Eperea 86, Belgrade, Serbia
}

Received 23.06.2014

Accepted 03.09.2014

\begin{abstract}
Understanding the reaction thermochemistry as well as formatting the empirical data about element distribution in gas-metal-slag phases is essential for creating a good model for aluminothermic and carbothermic reaction. In this paper modeling of material and energy balance of these reactions is described with the algorithm. The software, based on this model is basically made for production of high purity ferro alloys through aluminothermic process and then extended for some carbothermic process. Model validation is demonstrated with production of $\mathrm{FeTi}, \mathrm{FeW}, \mathrm{FeB}$ and $\mathrm{FeMo}$ in aluminothermic and reduction of mill scale, pyrite cinders and magnetite fines in carbothermic process.
\end{abstract}

\section{Introduction}

Aluminothermic reactions are thermite reactions in witch aluminum metal reacts with some metal oxide reducing it to the pure metal. These reactions are highly exothermic and self-propagating so only initiation is needed to complete the reaction. However, energy of reaction depends on various parameters and it its adjustment can be done by designing of thermite mixture. Aluminothermic reaction has found many applications in production of metals and alloys, welding and coating $[1,2]$.

In literature there is a lot of data on production, kinetics of reaction, preparation of thermite mixture, effects of additions on metal yield etc $[1,2]$. Theoretical modeling for the equilibrium for the aluminothermic modeling of these reactions, as well as effects of salt additions can be done by software package FactSage or HSC [3, $4,5]$. However these software packages are not specialized for aluminothermic processes and do not include empirical studies. At this paper the preparation of

* Corresponding author: Vaso Manojlović, v.manojlovic@itnms.ac.rs 
thermite mixture and the production of $\mathrm{FeTi}, \mathrm{FeW}, \mathrm{FeB}$ and $\mathrm{FeMo}$ based on previous empirical studies were described. This was done by using the software "RikiAlC", developed primarily for the aluminothermic processes and extended for some carbothermic processes. The various ores and metal-oxides can be used for producing the FeTi [3, 5], FeW [6], FeB [7, 8], FeMo [9]. For carbothermic reaction primarily the mixture of a mill scale, pyrite cinders and magnetite fines are used. Carbothermic reactions are performed in electric arc furnace. Real data about element distribution, metal yield, and energy of reactions are used for adapting the theoretical model with empirical results.

\section{Materials and methods}

In reduction processes of complex oxide system with aluminium, rates and temperatures of reactions are very high. In addition, the presences of a large number of metal oxides complicate the course of the reaction. Thus, modeling of these reactions is very difficult and inaccurate if they are conducted without any empirical studies. Aluminothermy reduction processes for the production of ferro alloys with poorly soluble metals are conducted in semi-industrial conditions with different amounts of raw materials. Ore concentrates such as ilmenite, scheelite, boron and molybdenum ores with a high metal and low impurity content were the main raw material for these processes. The average chemical composition is given in a table 1 .

Table 1 The chemical composition of basic raw material for ferro-alloys production

\begin{tabular}{lllll}
\hline Component & \multicolumn{4}{c}{ Raw materials } \\
\hline & Ilmenite & Scheelite & Mo-conc. & B - ore \\
\cline { 2 - 5 } & 40,23 & 8,76 & - & - \\
$\mathrm{TiO}_{2}$ & 42,55 & & - & - \\
$\mathrm{WO}_{3}$ & - & 61,55 & 1,26 & - \\
$\mathrm{MoO}_{3}$ & - & - & 95,70 & - \\
$\mathrm{B}_{2} \mathrm{O}_{3}$ & - & - & - & 38,5 \\
$\mathrm{SiO}_{2}$ & 2,25 & 3,34 & - & 11,37 \\
$\mathrm{CaO}$ & 1,68 & 16,28 & - & 19,6
\end{tabular}

Aluminum powder with $>99 \%$ of aluminium and ferro-silicon with about $75 \%$ of $\mathrm{Si}$ were used as reducing agent. Lime with $90 \%$ of $\mathrm{CaO}$ is used as flux. The pure iron chips are used to reduce exothermic effect, such as in the case of FeW and FeMo production. Sodium nitrate with $95 \%$ of $\mathrm{NaNO}_{3}$ is used to increase exothermic effect of aluminothermic reactions, such as in the case of $\mathrm{FeTi}$ and $\mathrm{FeB}$ production. The reaction of sodium-nitrate with aluminum powder is extremely spontaneous with released energy of $8743 \mathrm{~kJ} / \mathrm{kg}$, and can be present as:

$$
6 \mathrm{NaNO}_{3}+10 \mathrm{Al}=3 \mathrm{Na}_{2} \mathrm{O}+3 \mathrm{~N}_{2}(\mathrm{~g})+5 \mathrm{Al}_{2} \mathrm{O}_{3}
$$

The aluminothermic reactions are conducted in crucible with magnesite refractory and capacity of $0.03 \mathrm{~m}^{3}$. After initiation aluminothermic reaction should be spontaneous and require no additional energy. 
In carbothermic reactions the mixture of a mill scale, pyrite cinders, magnetite fines, coke, lime and silica sand are used. The average chemical composition of basic mixture components is given in the table 2.

Table 2 The chemical composition of mill scale, pyrite cinders and magnetite fines

\begin{tabular}{cc|cc|cc}
\hline \multicolumn{2}{c|}{ Mill scale } & \multicolumn{2}{c|}{ Pyrite cinders } & \multicolumn{2}{c}{ Magnetite fines } \\
\hline $\mathrm{FeO}$ & 68.2 & $\mathrm{Fe}$ & 57.2 & $\mathrm{Fe}_{3} \mathrm{O}_{4}$ & 55.0 \\
$\mathrm{Fe}_{2} \mathrm{O}_{3}$ & 24.7 & $\mathrm{O}$ & 31.2 & $\mathrm{Fe}_{2} \mathrm{O}_{3}$ & 2.6 \\
$\mathrm{MnO}$ & 0.12 & $\mathrm{SiO}_{2}$ & 8.21 & $\mathrm{FeO}(\mathrm{OH}) \cdot \mathrm{nH}_{2} \mathrm{O}$ & 33.7 \\
$\mathrm{CaO}$ & 0.54 & $\mathrm{~S}$ & 1.17 & $\mathrm{SiO}_{2}$ & 5.2 \\
$\mathrm{Al}_{2} \mathrm{O}_{3}$ & 0.18 & $\mathrm{Al}_{2} \mathrm{O}_{3}$ & 0.82 & $\mathrm{MgO}$ & 1.7 \\
$\mathrm{SiO}_{2}$ & 0.81 & $\mathrm{Zn}$ & 0.34 & $\mathrm{Al}_{2} \mathrm{O}_{3}$ & 1.7 \\
$\mathrm{MgO}$ & 0.22 & $\mathrm{Cu}$ & 0.24 & & \\
$\mathrm{~S}$ & 0.03 & $\mathrm{~Pb}$ & 0.28 & & \\
others & 5.20 & others & 0.54 & &
\end{tabular}

The coke was used as reducing agent in carbothermic reactions. The mixture was prepared in pelletizer. The size of pellets was $80 \%<9 \mathrm{~mm}$. Prepared pellets are melted in $50 \mathrm{~kW}$ DC arc furnace.

In starting experiments the content of mixture is evaluated from theoretical calculation of material and energy balance. In order to determinate the element distribution in metal, slag and gas phase, chemical and phase analysis of products was performed. The chemical analysis was done on the atomic-absorption spectrophotometer (AAS) Perkin Elmer model ANALYST 300. The samples were prepared by dissolving in mineral acids to determine elements in them to AAS. The phase composition of the slag and raw materials was determined by X-ray analysis using diffractometer PHILIPS PW-1710. Petrography analysis of the slag was done on the transmission light microscopy, on Carl Zeiss-Jena, Polarized Light Microscope.

Model was modified according to these results. By repeating of experiments the model becomes more accurate and optimized for a given conditions.

Modeling and creating a database

The software RikiAlC was made on Microsoft Office Excel interface, based on the algorithm for aluminothermic/carbothermic process shown on the Figure 1.

The modeling of material balance in this software starts with imputing the chemical and phase composition of raw materials. In the software there is a standard chemical composition of a mill scale, electric arc furnace dust, pyrite cinders, magnetite fines, ilmenite, scheelite, boron and molybdenum ores, coke, lime, silica sand, aluminium powder and other additional materials. With chemical or phase analyses it is possible to define all input materials. By introduction the input raw materials, calculations of slag basicity and oxygen level are given, so that it is possible to adjust their values. 


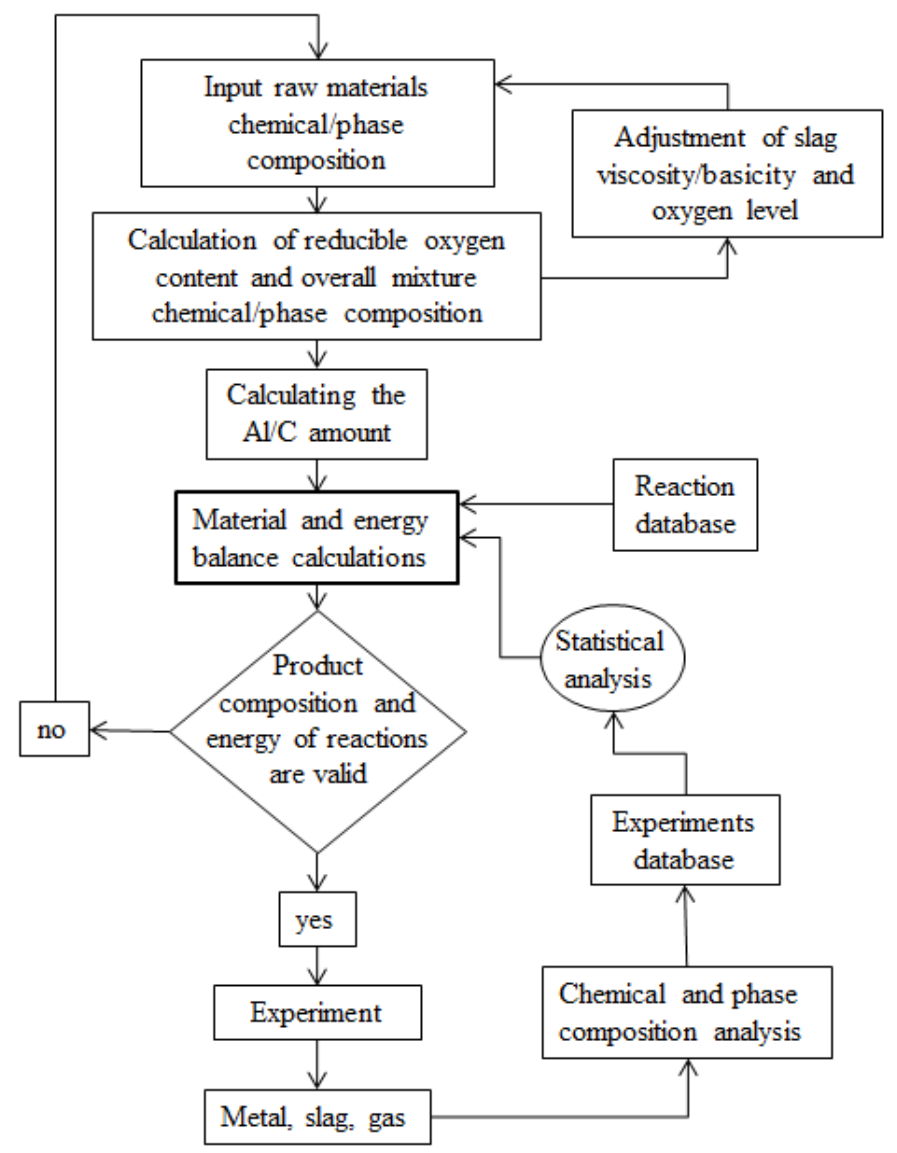

Figure 1 Algorithm for modeling of material and energy balance

Oxygen level in the total mixture is calculated by the following equations:

$$
\%(O)=\Sigma(\% O)_{M e}
$$

where $\Sigma(\% O)_{M e}$ are all oxides from metal which involves in reactions.

The slag basicity B is calculated by [10]:

$$
B=\frac{\sum(\text { basic oxides }), k g}{\sum(\text { acidic oxides }), k g}
$$

For carbothermic reaction slag basicity have significant role in terms of proper progress of the reactions and element distribution in metal, slag and gaseous phase [11] The slag basicity in carbothermic reactions is adjusted primarily by amounts of silica 
sand and lime. In aluminothermic reactions slag viscosity has significant role primarily due to the separation of metal and slag. Slag viscosity directly dependent on the temperature $[10,11]$. Adjusting the temperature of reaction is possible through addition of sodium nitrate in order raise, or iron chips in order to lower the temperature. In some aluminothermic reaction were exothermic effects are high (production of FeW, FeMo) the ferrosilicon was applied due to its low price on the market.

For aluminothermic and carbothermic reaction all oxides which involve in reactions are included in calculation of oxygen amount, based on Gibbs energies on a given temperature based on literature data. There are over 50 aluminothermic and carbothermic reactions in the database for temperatures ranges from 0 to $2500{ }^{\circ} \mathrm{C}$. The required amount of aluminium and carbon is calculated based on oxygen amount and multiplied with coefficients of 1.2 and 1.5 respectivelly. These coefficients are derived from experimental experience and are essential for the complete evaluation of overall reactions.

Output results are: model and experimental material balance, element distribution in gas-metal-slag phases as well as energy balance. The experimental data are collected and stored in database. With statistical analysis of these data, the mean values are taken to adjust material and energy calculations in the model. With element distribution in metal, slag and gas phase it is possible to determinate which reactions dominate and in which apportion. Consecutively, the energy of overall reactions is calculated with more precision. For aluminothermic reactions if released energy is too high the pure iron is added in raw materials, so the part of that energy is used for melting the pure iron. Otherwise, if released energy is insufficient, the sodium nitrate is used to increase exothermic effect of aluminothermic reaction. The annealing of raw materials leads to transition of the higher oxidation level to the lower. For example by transition of $\mathrm{Fe}_{2} \mathrm{O}_{3}$ to $\mathrm{FeO}$ in the mill scale, oxygen level is reduced in the mixture and exothermic effect is adjusted.

In carbothermic reactions, energy efficiency is in dependent from reactor type and carbon monoxide utilization. The $50 \mathrm{~kW}$ DC arc furnace was used in model energy balance calculations without taking into account the reaction:

$$
2 \mathrm{CO}(\mathrm{g})+\mathrm{O}_{2}(\mathrm{~g})=2 \mathrm{CO}_{2}(\mathrm{~g}) \quad \Delta \mathrm{H}_{300}=-6444.7 \mathrm{~kJ} / \mathrm{kg} \mathrm{CO}(\mathrm{g})
$$

that occurs outside of the reactor area.

The RikiAlC software was modeled for laboratory pilot scale furnace, so burning of $\mathrm{CO}(\mathrm{g})$ occurs outside of the furnace and is not taken into account. The required electric power consumption is calculated based on reduction of ore oxides with carbon and partly with carbon monoxide.

Model validations

\section{Ferrotitanium (FeTi) alloys production}

For obtaining of ferrotitanium alloys the mixture of ilmenite concentrate, aluminium powder, ferrosilicon, lime, fluorspar and sodium nitrate was used. For compete reaction of a given mixture the specific heat of the process should be above $2300 \mathrm{~kJ} / \mathrm{kg}$ of mixture. With semi-empirical model it was calculated that the mixture energy is insufficient for complete reaction. For this purpose the mill scale was added to 
increase specific heat to $2770 \mathrm{~kJ} / \mathrm{kg}$ of mixture. The process is carried out at a temperature of $1980{ }^{\circ} \mathrm{C}$, which is sufficient to ensure proper segregation of slag and metal products.

It is known that the titanium with silica forms a stable compound, with respect to aluminium. Therefore, a mixture of ferrosilicon was added which caused the minimization of aluminium content in the alloy. At the same time, utilization of titanium from ore is higher, because the silicon moves reaction in the direction of the transition of titanium in the metal.

The chemical composition of the cast ferrotitanium ranges within the following limits: $25-30 \%$ of $\mathrm{Ti} ; 3-5 \%$ of $\mathrm{Si} ; 3-7 \%$ of $\mathrm{Al}$; $\mathrm{C}$ max. $0.2 \%$; $\mathrm{S}$ max. $0.03 \%$ and $\mathrm{P}$ max. $0.07 \%$. Chemical analysis of the slag showed the following results: $69.5 \%$ of $\mathrm{Al}_{2} \mathrm{O}_{3}$; $13.56 \%$ of $\mathrm{TiO}_{2} ; 1.6 \%$ of $\mathrm{SiO}_{2} ; 0.3 \%$ of $\mathrm{CaO}$. From the Petrography analysis of slag it was noted that the main mineral phases are prismatic and tabular crystals of corundum, as well as fine-grained perovskite $\left(\mathrm{CaTiO}_{3}\right)$. Cement phase consists of glass. Utilization of titanium was $60-75 \%$.

\section{Ferroboron ( $\mathrm{FeB}$ ) alloys production}

For obtaining of ferroboron alloys with aluminothermic reaction, according to the software for determining the conditions of the process, the required amount of thermite additives is considerable because the reduction of the $\mathrm{B}_{2} \mathrm{O}_{3}$ anhydrous extracts only $3268 \mathrm{~kJ} / \mathrm{kg}$ oxides. For optimal performance of the reaction, the specific heat of the process is $5363 \mathrm{~kJ} / \mathrm{kg}$, which is provided by calculated amount of aluminium powder, sodium nitrate and mill scale. The optimal ratio of boron ore, mill scale, and aluminum was calculated to be $1.7: 1: 1$. By adding lime and fluorspar the viscosity of the slag was regulated.

Since boron ores containing molecular water, previously annealing is necessarily. This procedure should be carried out carefully. Otherwise, during annealing process up to $20 \%$ of boron can be lost. Also, the annealing process has great impact of transition of boron in metal during the aluminothermic process.

Due to the high affinity of boron to oxygen and nitrogen, alloy is hold to mold to room temperature, in order to avoid absorption of these gases in the metal. The resulting alloy contained $10-13 \%$ of $\mathrm{B} ; 4-7 \%$ of $\mathrm{Si}$ and up to $10 \%$ of Al. Average chemical content of slag was: $68.6 \%$ of $\mathrm{Al}_{2} \mathrm{O}_{3} ; 19.13 \%$ of $\mathrm{CaO} ; 2.1 \%$ of $\mathrm{MgO} ; 7.4 \%$ of $\mathrm{B}_{2} \mathrm{O}_{3}$. Mineral phase analysis shows that in addition to aluminum oxide, as a main phase, magnesium spinel is substantially represented. The utilization of boron from ore was $45-60 \%$, and the highest degree of efficiency was achieved with rate of $\mathrm{CaO}$ and $\mathrm{Al}_{2} \mathrm{O}_{3}$ of $0.20-0.25$ in the slag [12].

\section{Ferrowolfram $(\mathrm{FeW})$ alloys production}

Aluminothermic reactions release heat is sufficient to reduce the components in the mixture and for good separation of metal from slag. For this reason, the part of aluminium powder has been replaced with cheaper ferrosilicon by proportion modeled in the software. Since scheelite concentrate was very fine-grained (grain size less than $0.075 \mu \mathrm{m}$ ), it was pelleted with the aluminum powder and ferrosilicon. Average chemical composition of obtained ferrowolfram was: $73.34 \% \mathrm{~W} ; 0.45 \mathrm{Si} ; 0.93 \% \mathrm{Al}$; $0.07 \% \mathrm{~S}$ and $0.03 \% \mathrm{P}$. Utilization of wolfram was from 95 to $97 \%$. 


\section{Ferromolybdenum (FeMo) alloys production}

Iron and molybdenum can be alloyed in almost all proportions. With $36 \%$ of molybdenum eutectic mixture is formed with a melting point of $1440{ }^{\circ} \mathrm{C}$. In the composition of $60 \% \mathrm{Mo}$ and $40 \% \mathrm{Fe}$, the melting point is $1800{ }^{\circ} \mathrm{C}$. Consequently, projected alloy composition modifies the temperature of the reaction. In the software this is solved by calculating the energy of reactions and then modifying the composition of mixture. For optimum performance of the ferromolybdenum obtaining process, the specific heat of process should be $2300 \mathrm{~kJ} / \mathrm{kg}$ oxide, which can be easily achieved using the ferrosilicon as reducing agent. Humidity of the used molybdenum concentrate was up to $15 \%$, so previous drying and annealing was performed. Lime and fluorspar was used as a flux. The interrelation of components in the mixture and the thermodynamic conditions of the process are defined in such a way that the content of $\mathrm{Si}$ in ferromolybdenum was below $0.5 \%$.

The average chemical composition of ferro molybdenum was: $64.67 \%$ Mo; $0.21 \% \mathrm{Si} ; 0.1 \% \mathrm{Al} ; 0.06 \% \mathrm{~S}$ and $0.03 \% \mathrm{P}$. Slags are been characterized by the following average chemical composition: $66.5 \% \mathrm{SiO}_{2} ; 12.56 \% \mathrm{Al}_{2} \mathrm{O}_{3} ; 0.64 \% \mathrm{MoO}_{3}$; $6.45 \% \mathrm{CaO} ; 2.35 \% \mathrm{CaF}_{2}$.

\section{Carbothermic reduction}

The carbothermic reduction is conducted in order to achieve valorization of iron, zinc-oxide and lead-oxide from mill scale, pyrite cinders and magnetite fines. The proportion of mill scale, pyrite cinders and magnetite fines in a mixture was 30:50:20. The coke amount was $18.3 \%$ and lime was $5.3 \%$. Working temperature in the furnace is calculated at $1600{ }^{\circ} \mathrm{C}$. The melting point of slag is calculated to be $1133{ }^{\circ} \mathrm{C}$, which was confirmed by experiments. The projected slag basicity was 0.99 . Energy consumption of $1920 \mathrm{~kW}$ per ton of mixture was calculated.

After melting process, the chemical analysis of iron, slag and baghouse dust was done. Chemical composition of iron was: $98.2 \% \mathrm{Fe} ; 1.41 \% \mathrm{C} ; 0.07 \% \mathrm{~S} ; 0.04 \% \mathrm{P}$; $0.02 \% \mathrm{Cu}$. Chemical composition of slag was: $38.9 \% \mathrm{SiO}_{2} ; 34.5 \% \mathrm{CaO} ; 12.6 \% \mathrm{Al}_{2} \mathrm{O}_{3}$; $4.1 \% \mathrm{FeO} ; 4.0 \% \mathrm{MgO} ; 0.2 \% \mathrm{MnO}$. Chemical composition of the baghouse dust was: $15.4 \% \mathrm{ZnO} ; 8.6 \% \mathrm{PbO} ; 51.3 \% \mathrm{SO}_{3}$.

\section{Conclusions}

Semi empirical software was developed primarily for aluminothermic reaction and extended for some carbothermic reaction. The software is design to give an optimal mixture for aluminothermic/carbothermic reactions based on material and energy balance model. At this paper the successful production of FeTi, FeW, FeB and FeMo has been shown in aluminothermic reaction using the software RikiAlC. For carbothermic reaction reduction of mixture with the mill scale, pyrite cinders and magnetite fines to metallic iron was done. Basic principles and algorithm for modeling of these processes has been shown.

Further work should be done on finding the correlations between aluminothermic productions of individual ferro-alloys to model a production of complex ferro-alloys. Also, the reversible engineering should be developed in the software. For example, with a given ferro-alloy composition, software should automatically suggest optimal mixture 
composition for aluminothermic reaction. For now, optimal mixture composition can be found by manually adjustment of mixture composition.

\section{Acknowledgement}

This research was performed with the financial support of the Ministry of Education, Science and Technological Development of the Republic of Serbia and it is a result of projects No 34002 Development of technological casting procedures under the influence of electromagnetic fields and plastic processing technology in the hot state of four-components $\mathrm{Al}-\mathrm{Zn}$ alloys for special applications and No 34033 Innovative synergy of by-products, waste minimization and cleaner technology in metallurgy.

\section{References}

[1] A. Maleki, M. Panjepour, B. Niroumand, M. Meratian, J. Mater. Sci. 45 (2010) 5574-5580.

[2] J. Meia, R.D. Halldearna, P. Xiaoa, Scr. Mater. 41 (1999) 541-548.

[3] V. Babyuk, B. Friedrich, V. Sokolov, World Metall. 60 (2007) 255-261.

[4] M.M. Eissa, K.A. El- Fawakhry, M.L. Mishreky, H.R.EI Faramawy, In: Proceedings INFACON'12. Eds.: A. Vartiainen, Outotec Oyj 2010, p. 431.

[5] V.M. Chumarev, A.Ya. Dubrovskii, I.P. Pazdnikov, Yu.Yu. Shurygin, N.I. Sel'menskikh, Russ. Metall. 2008 (2008) 14-19.

[6] C. Ii. Gupta and p. K. Jena, J. Less-Common Met. 13 (1967) 269-273.

[7] O. Yücel, F. Cinar, O. Addemir, A. Tekin, High Temp. Mater. Processes 15 (1996) 103-110.

[8] J.L. Andrieux, R. Peffen, US3016288 (1968)

[9] A.K. Suri, T.K. Mukherjee, C.K. Gupta, In: Proceedings of the Seminar on Problems and Prospects of Ferro-Alloy Industry in India, NML, Jamshedpur, Oct. 24-26, 1983 p.200.

[10] Ž. Živković, V. Savović, Fizičko-hemijske osnove procesa topljenja i konvertovanja u metalurgiji bakra, Technical Faculty in Bor (1996)

[11] K.S. Coley, J. Min. Metall. Sect. B-Metall. 49 B (2013) 191 - 199.

[12] J. Pearson, Steel Technol. Int. (1989) 141-148. 